\title{
Impact of Multichannel Integration Service Quality on Retailer Brand Equity: The Mediating Role of Brand Trust
}

\author{
Yongzhi Qi*, Kexin Liang, Zhijia Liu \\ Faculty of Business Administration, Shanxi University of Finance \& Economics, Taiyuan 030006, China
}

Corresponding Author E-mail: qiyz@sxufe.edu.cn

https://doi.org/10.18280/ijsdp.150419

Received: 17 November 2019

Accepted: 2 April 2020

\section{Keywords: \\ multichannel retailing, multichannel integration service quality (MCISQ), Brand trust $(B T)$, retailer brand equity $(R B E)$}

\begin{abstract}
Retailer brand equity (RBE) is a major source of competitiveness of brand retailers. As the retail industry strives to integrate online and offline channels, it is of great significance to enhance the RBE by improving multichannel integration service. This paper develops a theoretical framework to examine the impacts of the MCISQ on the RBE, with brand trust (BT) as the intermediary. The data were collected through a questionnaire survey on 462 consumers with online and offline shopping experiences in the same retailer. The results show that, in the multichannel retailing environment, the MCISQ has significant positive impacts on the RBE and the BT; the BT exerts a significant positive impact on the RBE, and partially mediates the relationship between the MCISQ and the RBE; the BT is an important driver of the effect of the MCISQ on the RBE. The research findings enable retailers to improve the MCISQ, establish the BT, and enhance brand equity.
\end{abstract}

\section{INTRODUCTION}

According to McKinsey's Report on China Digital Consumer Trends in 2017, multichannel shopping that integrates online and offline channels has become the mainstream consumption pattern. For example, 93\% of respondents choose multichannel shopping to purchase electronic products. To support seamless multichannel shopping, retailers, namely, Amazon, Alibaba, Jingdong, Suning, Uniqlo, Guerlain, and Freshhema, are competing to provide consumers with multichannel integration service (MCIS), which fully leverages the complementary of offline physical channel and online electronic channel.

Many studies have shown that consumer perception of the MCIS affects their satisfaction with and loyalty to a brand, and thus influences the brand value and retailer profit [1-3]. For retailers, it is important to evoke differentiated response from consumers through various means, namely, service provision, channel building, and channel integration. In the brand domain, this is to enhance the retailer brand equity (RBE), i.e. the unique worth of retailer brand perceived by consumers through retailer-consumer interaction.

How to improve brand equity has long been a research hotspot. Some scholars have demonstrated that brand equity is affected by store image [4], consumer satisfaction [5], brand trust (BT) [6], and service quality [7]. As the retail industry strives to integrate online and offline channels, it is very meaningful to disclose how the MCISQ affects the RBE.

Drawing on relevant theories, this paper models the impact of the MCISQ on retailer brand quality, with the BT as the intermediary, and empirically explores the interaction between the MCISQ, the BT, and the RBE. In this way, the authors revealed the impact mechanism between these factors, highlighting the mediating role of the BT in the relationship between the MCISQ and the RBE. The research findings are of theoretical and practical significance to the improvement of the RBE.

The remainder of this paper is organized as follows. Section 2 reviews the previous literature and explains the relevant concepts; Section 3 presents the conceptual model and research hypotheses; Section 4 details the questionnaire design; Section 5 fully analyzes the survey data; Section 6 puts forward the conclusions and strategies for improving the RBE.

\section{LITERATURE REVIEW}

\subsection{The MCISQ}

The MCISQ refers to the service quality in the new retailing environment, which is featured by the integration between online and offline channels. From the retailer's perspective, the MCISQ means the ability of a retailer to provide consumers with seamless services across channels [8]. From the consumer's perspective, the MCISQ can be defined as the ability of a consumer to perceive high-quality services consistently as he/she crosses the physical, electronic, and other channels of a retailer.

As a comprehensive concept, the MCISQ spans across multiple dimensions. Sousa and Voss [8] developed a fourdimensional framework of the MCISQ, covering the degree of freedom in channel selection, structural transparency of channel services, content consistency, and process consistency. Later, Oh and Teo [9] divided retailer MCIS in online-tooffline $(\mathrm{O} 2 \mathrm{O})$ scenario into six dimensions: integration of promotion information, integration of product and price information, integration of transaction information, integration of information integration, integration of order 
fulfilment, and integration of consumer services. Cao and $\mathrm{Li}$ [10] held that retailer MCIS should involve the following aspects: integration of marketing and communication, integration of order fulfilment, integration of information acquisition, basic configuration, back-end centralization, and organizational transform. In this paper, Oh and Teo's [9] division of retailer MCIS is adopted to explore retail brand equity, because the division measures the MCISQ from the perspective of consumers.

\subsection{Retailer brand equity}

The RBE refers to the brand equity in the new retailing environment. It is a major source of competitiveness of brand retailers. Ailawadi and Keller [11] defined the RBE as the differentiated response of consumers to retailer marketing, stemming from their knowledge of the retailer brand. From the angle of consumers, Pappu and Quester [5] pointed out the $\mathrm{RBE}$ is the value of retailer brand perceived by consumers, i.e. the differentiated response of consumers to the retailer of a specific brand. From the perspective of consumers, Jara and Cliquet [12] suggested that the RBE is the value that the retailer creates through his/her store and the combination of products, services, and experiences within the store. In this paper, the RBE is defined as the consumer's differentiated response to a specific brand retailer.

The RBE can be measured by one dimension or multiple dimensions. In one-dimensional measurement, the RBE is viewed as a holistic variable. For instance, White et al. [13] measured the holistic the RBE with five items. In multidimensional measurement, the RBE is generally treated as a comprehensive concept. For example, Pappu and Quester [14] evaluated the RBE with four metrics, such as retailer awareness, retailer association, retailer perceived quality, and retailer loyalty. Specifically, retailer awareness refers to the ability of consumers to identify or recall a particular retailer; retailer association refers to the impression that consumers associate with a particular retailer; retailer perceived quality is a holistic concept about consumer perception of the overall quality of a particular retailer; retailer loyalty refers to the willingness of consumers to purchase products from a particular retailer. This paper adopts the evaluation metrics proposed by Pappu and Quester to analyze the RBE.

\subsection{Brand trust}

Brand trust is often associated with risk and experience. Dick and Basu [15] believed that the BT is the degree to which consumers determine their trust and confidence in a brand through risk perception and risk prediction under risky conditions. Munuera-Aleman et al. [16] argued that when consumers are at risk, the dependence, expectation, confidence, and consumer behavior of the brand denote trust. Krishnan [17] considered the cumulative experience of consumers in a brand as an important source of the BT, because the experience promotes the association with and reflections on a specific brand. Garbarino and Johnson [18] claimed that the BT evolves from previous brand experiences and consumer-brand interactions, and outlines the consumer knowledge and experiences of the brand. In this paper, the BT is understood as consumer reliance and confidence over the retailer, which stem from the cumulative brand experience under risky conditions.

The BT can be measured by one, two or three dimensions. In one-dimensional measurement, the BT is directly measured by multiple items $[19,20]$. In two-dimensional measurement, the BT is broken down into trustworthiness (the brand's willingness to honor its promises) and expertise (the brand's competence to honor its promises) [21]. In three-dimensional measurement, the BT is split into three dimensions: brand reputation, brand predictability, and brand competence [22].

\section{CONCEPTUAL MODEL AND HYPOTHESES}

\subsection{Conceptual model}

Based on relevant literature and retail practice, this paper proposes a conceptual model of the relationship between the MCISQ and the RBE (Figure 1).

There are four hypotheses of the above model:

H1. The MCISQ has a positive impact on the RBE;

H2. The MCISQ has a positive impact on the BT;

$\mathrm{H} 3$. The BT has a positive impact on the RBE;

H4. The BT mediates the relationship between the MCISQ and the RBE.

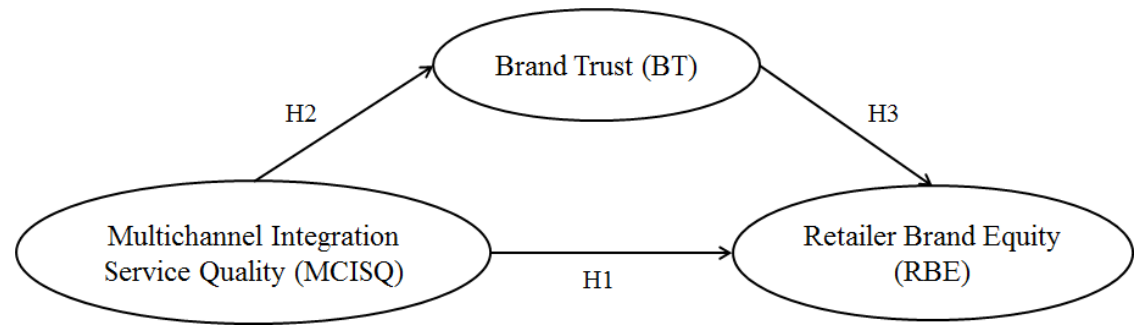

Figure 1. The conceptual model

\subsection{Hypotheses}

\subsubsection{Relationship between the MCISQ and the RBE}

The relationship between the MCISQ and the RBE is the extension of the relationship between the service quality and brand equity into the multichannel retailing environment. The previous studies $[23,24]$ have shown that the improvement of service quality affects that of brand equity. Jahanzeb et al. [7] suggested that consumers distinguish brands by service quality, which influences consumer-based brand equity.

Consumer loyalty is an important dimension of the RBE. To elevate the RBE, it is necessary to enhance the brand loyalty by providing consumers with a seamless shopping environment and the freedom to choose from multiple channels [2, 3] [25]. Therefore, the MCISQ affects each and all dimensions of the RBE. On this basis, the relationship 
between the MCISQ and the RBE was hypothesized as follows: H1. The MCISQ has a positive impact on the RBE.

\subsubsection{Relationship between the MCISQ and the BT}

The MCISQ is the perceived quality of online-offline integrated services, whereas the BT is the aggregation of online and offline brand trusts. Many studies [26, 27] have demonstrated the positive correlation between service quality and the BT. In the multichannel retailing environment, the MCISQ also exerts a positive impact on the BT. In the presence of risk, the BT will emerge and take effect. The integration between online and offline channels will reduce the consumer's risk perception of online stores [28], augment online trust, and aggrandize the consumer's BT.

Some scholars proved that the BT could be improved by the consistency of information in multichannel integration. Liao et al. [29] held that an enterprise will lose the trust of consumers, if its multichannel strategies are perceived discontinuously, or if its products are inconsistent. In summary, the BT is affected by each and all dimensions of the MCISQ. On this basis, the relationship between the MCISQ and the BT was hypothesized as follows:

H2. The MCISQ has a positive impact on the BT.

\subsubsection{Relationship between the BT and the RBE}

The loyalty, as a dimension of brand equity, appears when a consumer repeatedly chooses a retailer, because he/she trusts the retailer's brand. $\mathrm{Hu}$ et al. [6] modelled the relationship between trust and brand equity, revealing the positive effect of trust on brand equity and brand performance. The BT directly improves brand equity in all dimensions, especially the loyalty dimension $[19,20]$. Through empirical analysis on retailing and aviation, Sirdeshmukh et al. [30] confirmed that consumer trust in enterprises boosts consumer loyalty. Chiou and Shen [31] argued that trust reflects the cumulative effect of loyalty in high-involvement, high-service product markets. To sum up, the BT affects each and all dimensions of the RBE. On this basis, the relationship between the $\mathrm{BT}$ and the RBE was hypothesized as follows:

$\mathrm{H} 3$. The BT has a positive impact on the RBE.

\subsubsection{The mediating role of the BT}

The mediating role of the BT has been confirmed in studies on social psychology [32], management science [33], and organizational domains [34]. The mediating role of the BT also exists in retailer-consumer relationship. Marakanon and
Panjakajornsak [35] manifested the indirect impact of perceived quality on consumer loyalty via consumer trust. Besides, the BT mediates the correlation between the perceived quality and the RBE in the loyalty dimension. Liao et al. [29] believed that consumer trust will be affected by the integration degree of product information in the MCIS. Hence, the BT bridges up and mediates between the MCISQ and the RBT. On this basis, the mediating role of the BT was hypothesized as follows:

H4. The BT mediates the relationship between the MCISQ and the RBE.

\section{QUESTIONNAIRE DESIGN}

Our questionnaire was designed based on Likert's 7-point scale, where 1-7 respectively stand for strongly disagree, moderately disagree, slightly disagree, neutral, slightly agree, moderately agree, and strongly agree. As shown in Table 1, the questionnaire consists of four parts: the MCISQ, the BT, the RBE, and basic information.

Based on Oh and Teo's scale and dimensional division [9], the MCISQ was measured in the six dimensions: promotion information integration, product and price information integration, transaction information integration, information acquisition integration, order fulfilment integration, and consumer service integration. Based on the trust scale of Chaudhuri and Holbrook [19], the BT was measured with four items in one dimension. Based on the retailer equity scale of Pappu and Quester [14], the RBE was measured with 18 items in four dimensions: retailer awareness, retailer association, retailer perceived quality, and retailer loyalty

According to the 44th Statistical Report on China's Internet Development released by China Internet Network Information Center (CNNIC) in 2019, "As of June 2019, China's Internet users are still dominated by groups aged between 10 and 39, accounting for $65.1 \%$ of the total. Among them, the age group of 20-29 takes up the highest proportion (24.6\%)."

College students are the most representative persons in the age group of 20-29, and often purchase products from multiple channels. Therefore, our questionnaire survey was carried out among college students. A total of 550 questionnaires were distributed, and 512 questionnaires were retrieved. After screening, 462 questionnaires were found valid, putting the recovery rate and effective rate at $93.1 \%$ and $84 \%$, respectively. Table 2 lists the descriptive statistical features of the samples.

Table 1. The evaluation index system

\begin{tabular}{|c|c|c|c|}
\hline Variables & Dimensions & Abbreviations & Items \\
\hline \multirow{10}{*}{$\begin{array}{c}\text { MCISQ } \\
\text { [9] }\end{array}$} & \multirow{5}{*}{$\begin{array}{l}\text { Promotion information } \\
\text { integration }\end{array}$} & PII1 & $\begin{array}{c}\text { The brand name, slogan, and logo of the retailer are consistent between online and } \\
\text { offline stores. }\end{array}$ \\
\hline & & PII2 & $\begin{array}{l}\text { The retailer promotes its online store through the offline store, using instruments like } \\
\text { brochures, flyers, invoices, shopping bags, and posters. }\end{array}$ \\
\hline & & PII3 & $\begin{array}{c}\text { The retailer promotes its offline store through the media, namely, TV, website, and } \\
\text { official WeChat account. }\end{array}$ \\
\hline & & PII4 & $\begin{array}{c}\text { The retailer promotes the sales campaign of the nearby offline store through the online } \\
\text { store. }\end{array}$ \\
\hline & & PII5 & The retailer provides the address of its offline store in the online store. \\
\hline & \multirow{3}{*}{$\begin{array}{l}\text { Product and price } \\
\text { information integration }\end{array}$} & PPI6 & The retailer offers consistent product description in its online and offline stores. \\
\hline & & PPI7 & The retailer offers consistent product price in its online and offline stores. \\
\hline & & PPI8 & The retailer offers consistent inventory information in its online and offline stores. \\
\hline & \multirow{2}{*}{$\begin{array}{c}\text { Transaction information } \\
\text { integration }\end{array}$} & TII9 & The retailer merges and saves my transaction records in its online and offline stores. \\
\hline & & TII10 & $\begin{array}{l}\text { The retailer recommends products that may interest me based on my transaction records } \\
\text { in its online and offline stores. }\end{array}$ \\
\hline
\end{tabular}




\begin{tabular}{|c|c|c|c|}
\hline \multirow{4}{*}{\multicolumn{2}{|c|}{$\begin{array}{c}\text { Information acquisition } \\
\text { integration }\end{array}$}} & TII11 & $\begin{array}{l}\text { The retailer presents me a personalized webpage for transaction based on my transaction } \\
\text { records in its online and offline stores. }\end{array}$ \\
\hline & & IAI12 & I can search for product information of the offline store through the online store. \\
\hline & & IAI13 & I can check the inventory information of the offline store through the online store. \\
\hline & & IAI14 & $\begin{array}{l}\text { I can access the information of the online store through the terminal inquiry machine in } \\
\text { the offline store. }\end{array}$ \\
\hline \multirow{4}{*}{\multicolumn{2}{|c|}{ Order fulfilment integration }} & OFI15 & The retailer's coupons or points can be redeemed in its online store and offline store. \\
\hline & & OFI16 & The retailer allows online purchases and offline pick-up. \\
\hline & & OFI17 & The retailer allows online purchases and pick-up in the nearest offline store. \\
\hline & & CSI18 & The retailer allows online purchases and returns, repairs or exchanges in its offline store. \\
\hline \multirow{3}{*}{\multicolumn{2}{|c|}{$\begin{array}{l}\text { Consumer service } \\
\text { integration }\end{array}$}} & CSI19 & $\begin{array}{c}\text { The retailer's online store provides after-sales service for offline purchases through } \\
\text { online consumer service or e-mail. }\end{array}$ \\
\hline & & CSI20 & $\begin{array}{l}\text { The consumer service of the retailer's offline store provides services to consumers of the } \\
\text { online store through comment response and live chat. }\end{array}$ \\
\hline & & BTR21 & I trust the retailer brand. \\
\hline \multirow{4}{*}{\multicolumn{2}{|c|}{ BT [19] }} & BTR22 & The retailer brand is honest. \\
\hline & & BTR23 & The retailer brand is safe. \\
\hline & & BTR24 & I depend on the retailer brand. \\
\hline & & RAW25 & I am familiar with the retailer. \\
\hline \multirow{4}{*}{\multicolumn{2}{|c|}{ Retailer awareness }} & RAW26 & I can quickly recall the features of the retailer. \\
\hline & & RAW27 & I can recognize the retailer from many retailers. \\
\hline & & RAW28 & The retailer is impressive. \\
\hline & & RAW29 & The retailer is trustworthy. \\
\hline \multirow{14}{*}{$\mathrm{RBE}[14]$} & \multirow{5}{*}{ Retailer association } & RAS30 & The retailer offers a convenient shopping experience. \\
\hline & & RAS31 & The retailer creates a good shopping atmosphere. \\
\hline & & RAS32 & The retailer provides a wide range of products. \\
\hline & & RAS33 & The retailer is very attentive to consumer service. \\
\hline & & RAS34 & The retailer has good after-sales service. \\
\hline & \multirow{5}{*}{ Retailer perceived quality } & RPQ35 & The retailer provides timely services. \\
\hline & & RPQ36 & The retailer provides reliable services. \\
\hline & & RPQ37 & The retailer provides products with reliable quality. \\
\hline & & RPQ38 & The retailer provides products with high performance. \\
\hline & & RPQ39 & The retailer provides products with stable quality. \\
\hline & \multirow{4}{*}{ Retailer loyalty } & RLY40 & I am willing to shop again through the retailer. \\
\hline & & RLY41 & I make the retailer the first option for shopping. \\
\hline & & RLY42 & I will not choose another retailer if I can get products through the retailer. \\
\hline & & RLY43 & I am willing to recommend the retailer to my friends. \\
\hline
\end{tabular}

Table 2. Descriptive statistics of the samples

\begin{tabular}{|c|c|c|c|c|c|c|c|}
\hline Variable & Variable attribute & $\begin{array}{l}\text { Sample size } \\
\text { (person) }\end{array}$ & $\begin{array}{l}\text { Percentage } \\
(\%)\end{array}$ & Variable & Variable attribute & $\begin{array}{l}\text { Sample size } \\
\text { (person) }\end{array}$ & $\begin{array}{c}\text { Percentage } \\
(\%)\end{array}$ \\
\hline \multirow{3}{*}{ Gender } & Male & 121 & 26.2 & \multirow{5}{*}{ Online shopping experience } & Less than 1 year & 4 & 0.9 \\
\hline & Female & 341 & 73.8 & & $1-3$ years & 263 & 56.9 \\
\hline & $18-30$ & 457 & 98.9 & & $3-5$ years & 133 & 28.8 \\
\hline \multirow[t]{2}{*}{ Age } & $31-40$ & 3 & 0.6 & & More than 5 years & 62 & 13.4 \\
\hline & $41-50$ & 2 & 0.4 & & 1-5 times & 66 & 14.3 \\
\hline \multirow{7}{*}{ Education } & $\begin{array}{l}\text { Junior college graduate } \\
\text { and below }\end{array}$ & 6 & 1.3 & \multirow{3}{*}{$\begin{array}{l}\text { Annual shopping times at } \\
\text { the same retailer }\end{array}$} & $6-10$ times & 138 & 29.9 \\
\hline & & & & & 11-20 times & 120 & 26.0 \\
\hline & Bachelor & 420 & 90.9 & & 21 or more times & 138 & 29.9 \\
\hline & \multirow{2}{*}{ Master } & \multirow[b]{2}{*}{30} & \multirow{2}{*}{6.5} & \multirow{4}{*}{ Monthly disposable income } & $\begin{array}{l}\text { RMB 1,500 yuan } \\
\text { and below }\end{array}$ & 364 & 78.8 \\
\hline & & & & & $\begin{array}{c}\text { RMB } 1,501-3,000 \\
\text { yuan }\end{array}$ & 93 & 20.1 \\
\hline & \multirow{2}{*}{ Doctor } & \multirow{2}{*}{6} & \multirow{2}{*}{1.3} & & $\begin{array}{c}\text { RMB 3,001-4,500 } \\
\text { yuan }\end{array}$ & 4 & 0.9 \\
\hline & & & & & $\begin{array}{l}\text { RMB 4,501 yuan } \\
\text { and above }\end{array}$ & 1 & 0.2 \\
\hline
\end{tabular}

\section{DATA ANALYSIS}

\subsection{Reliability test}

The reliability of each latent variable was analyzed on SPSS24.0. As shown in Table 3, the reliability of every latent variable was greater than 0.7 . This means the survey data are highly reliable and suitable for further analysis.

\subsection{Confirmatory factor analysis (CFA)}

As a key step in structural equation model (SEM), the CFA, including first- and second-order CFA, assesses whether a group of variables belongs to a latent variable. The assessment relies on indices like factor loading, composite reliability (CR), and the average variance extracted (AVE) from the latent variables. 
Based on factor loading, CR, and AVE of the measurement model, first-order and second-order CFA were sequentially performed on each latent variable. Based on the analysis results (Table 4), the following were deleted: the items and first-order latent variables with a factor loading less than 0.5 ; the measurement models with a CR less than 0.7 and an AVE less than 0.5; the items with non-independent residual and large chi-square, and the second-order variables with poor goodness-of-fit. Next, the SEM was performed on the remaining items and latent variables.

\subsection{Discriminant validity analysis}

The discriminant validity of latent variables was tested by the AVE method of Amos 24.0. The AVE value reflects how much each item can explain the variance of the corresponding latent variable. As shown in Table 5, the square of each correlation coefficient is lower than the AVE of the latent variable. Therefore, the three latent variables, namely, MCISQ,
BT, and RBE all possess good discriminant validity.

\subsection{SEM analysis}

Table 6 displays the results of the general SEM (Figure 2). Obviously, the fitting results of the SEM conformed to the standard. The coefficients between MCISQ, BT, and RBE of the hypothetical model were invariably significant, indicating that $\mathrm{H} 1, \mathrm{H} 2$ and $\mathrm{H} 3$ hold.

By the Bootstrap method, the MCISQ was tested for mediation significance on 2,000 samples. There was no zero in the bias-corrected percentile (BCP) confidence intervals, suggesting the BT mediates the relationship between the MCISQ and the RBE. The total effect of the MCISQ on the RBE was 0.679 . The direct effect of the MCISQ on the RBE was 0.322 . The indirect effect of the MCISQ on the RBE was 0.357 . Therefore, the BT, as a partial intermediary, mediates $0.357 / 0.679=52.6 \%$ of the relationship between the MCISQ and the RBE. Thus, H4 is proved valid.

Table 3. The reliability of each latent variable

\begin{tabular}{cccccc}
\hline Variables (abbreviations) & $\begin{array}{c}\text { Number } \\
\text { of items }\end{array}$ & $\begin{array}{c}\text { Cronbach's } \\
\text { alpha }\end{array}$ & $\begin{array}{c}\text { Variables } \\
\text { (abbreviations) }\end{array}$ & $\begin{array}{c}\text { Number of } \\
\text { items }\end{array}$ & $\begin{array}{c}\text { Cronbach's } \\
\text { alpha }\end{array}$ \\
\hline Promotion information integration (PII) & 5 & 0.776 & Brand trust (BTR) & 4 & 0.840 \\
Product and price information integration (PPI) & 3 & 0.702 & Retailer awareness (RAW) & 5 & 0.924 \\
Transaction information integration (TII) & 3 & 0.752 & Retailer association (RAS) & 5 & 0.854 \\
Information acquisition integration (IAI) & 3 & 0.765 & Retailer perceived quality (RPQ) & 4 & 0.756 \\
Order fulfilment integration (OFI) & 3 & 0.814 & Retailer loyalty (RLY) & 4 & 0.811 \\
Consumer service integration (CSI) & 3 & 0.757 & & \\
\hline
\end{tabular}

Table 4. The CFA results of each latent variable

\begin{tabular}{|c|c|c|c|c|c|c|c|c|c|}
\hline \multirow{2}{*}{ Variables } & \multirow{2}{*}{ Dimensions } & \multicolumn{4}{|c|}{ Parameter significance } & \multicolumn{2}{|c|}{ Index reliability } & \multicolumn{2}{|c|}{$\begin{array}{l}\text { Variable Convergence } \\
\text { reliability validity }\end{array}$} \\
\hline & & $\begin{array}{l}\text { Non-standardized } \\
\text { factor loading }\end{array}$ & $\begin{array}{l}\text { Standard } \\
\text { error }(\mathrm{SE})\end{array}$ & $\begin{array}{c}\text { CR } \\
\text { T-statistic }\end{array}$ & P-value & $\begin{array}{l}\text { Standardized } \\
\text { factor loading }\end{array}$ & $\begin{array}{l}\text { Squared multiple } \\
\text { correlation (SMC) }\end{array}$ & $\mathrm{CR}$ & AVE \\
\hline \multirow{9}{*}{ MCISQ } & $\begin{array}{l}\text { Promotion } \\
\text { information } \\
\text { integration }\end{array}$ & 1 & & & & 0.771 & 0.594 & \multirow{6}{*}{0.896} & \multirow{6}{*}{0.59} \\
\hline & $\begin{array}{l}\text { Product and price } \\
\text { information } \\
\text { integration }\end{array}$ & 1.01 & 0.112 & 9.049 & $* * *$ & 0.74 & 0.548 & & \\
\hline & $\begin{array}{c}\text { Transaction } \\
\text { information } \\
\text { integration }\end{array}$ & 0.888 & 0.1 & 8.875 & $* * *$ & 0.752 & 0.566 & & \\
\hline & $\begin{array}{l}\text { Information } \\
\text { acquisition } \\
\text { integration }\end{array}$ & 1.046 & 0.108 & 9.676 & $* * *$ & 0.766 & 0.587 & & \\
\hline & $\begin{array}{l}\text { Order fulfilment } \\
\text { integration }\end{array}$ & 0.872 & 0.097 & 9.013 & $* * *$ & 0.714 & 0.51 & & \\
\hline & \multirow[t]{2}{*}{$\begin{array}{l}\text { Consumer service } \\
\text { integration }\end{array}$} & 1.157 & 0.11 & 10.544 & $* * *$ & 0.858 & 0.736 & & \\
\hline & & 1 & & & & 0.829 & 0.687 & \multirow{3}{*}{0.901} & \multirow{3}{*}{0.752} \\
\hline & \multirow[t]{2}{*}{$\mathrm{BT}$} & 1.043 & 0.044 & 23.517 & $* * *$ & 0.906 & 0.821 & & \\
\hline & & 1.018 & 0.046 & 22.363 & $* * *$ & 0.868 & 0.753 & & \\
\hline \multirow{4}{*}{ RBE } & Retailer awareness & 1 & & & & 0.72 & 0.518 & \multirow{4}{*}{0.877} & \multirow{4}{*}{0.642} \\
\hline & Retailer association & 0.986 & 0.081 & 12.248 & $* * *$ & 0.871 & 0.759 & & \\
\hline & $\begin{array}{l}\text { Retailer perceived } \\
\text { quality }\end{array}$ & 1.041 & 0.085 & 12.237 & $* * *$ & 0.871 & 0.759 & & \\
\hline & Retailer loyalty & 0.861 & 0.084 & 10.209 & $* * *$ & 0.73 & 0.533 & & \\
\hline
\end{tabular}

Note: $* * *$ means $\mathrm{p}<0.001$ 
Table 5. The results of AVE-based discriminant validity analysis

\begin{tabular}{|c|c|c|}
\hline & MCISQ & BT RBE \\
\hline MCISQ & 0.590 & \\
\hline BT & 0.343 & 0.752 \\
\hline RBE & 0.473 & 0.5900 .642 \\
\hline
\end{tabular}

Note: The numbers on the diagonal are the AVEs of the corresponding latent variables; the numbers below the diagonal form the correlation coefficient matrix

Table 6. The results of the general SEM

\begin{tabular}{cccccccc}
\hline \multicolumn{2}{c}{ Variables } & Standardized coefficient & Non-standardized coefficient & SE & T-value & P-value \\
\hline MCISQ $\rightarrow$ & RBE & 0.354 & 0.343 & 0.058 & 5.932 & $* * *$ \\
MCISQ $\rightarrow$ & BT & 0.578 & 0.730 & 0.081 & 9.041 & $* * *$ \\
BT $\rightarrow$ & RBE & 0.565 & 0.434 & 0.047 & 9.243 & $* * *$ \\
\hline
\end{tabular}

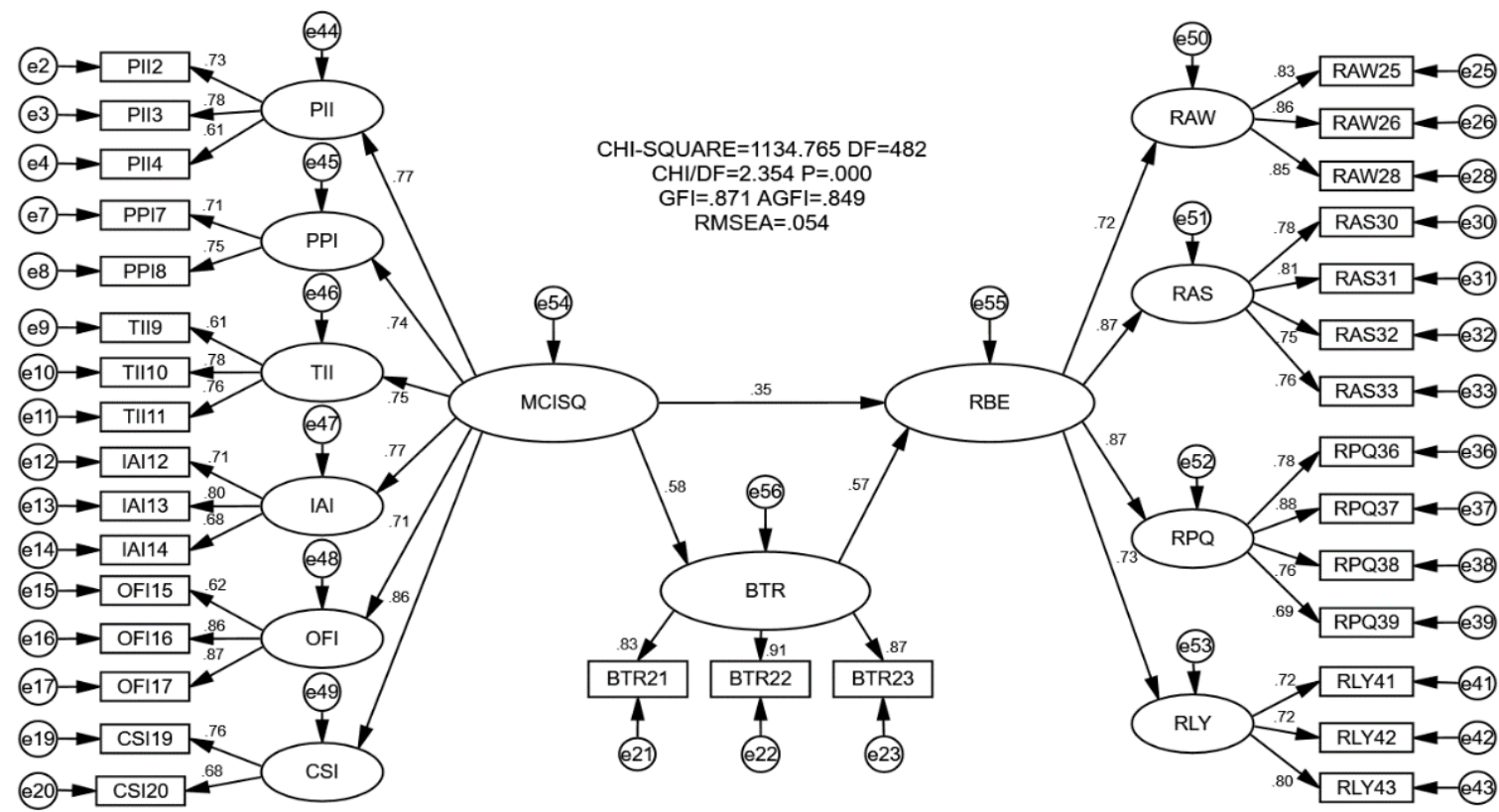

Figure 2. The general SEM

\section{CONCLUSIONS}

\subsection{The MCISQ and the BT have positive effects on the RBE}

The consumer's differential response to a retailer depends on his/her trust in the retailer brand. To enhance its brand equity, the retailer should adopt a twin-track approach.

First, the retailer should improve the MCISQ in the multichannel retailing environment, evoking the differential response from consumers. The MCISQ could be improved by promoting the integration of promotion information, product and price information, transaction information, information acquisition, order fulfilment, and consumer service.

Second, the retailer needs to build the BT, the catalyst of retailer equity, and make consumers feel that its brand is safe, honest, and trustworthy.

\subsection{The MCISQ has a positive effect on the BT}

For consumers, the retailers that provide high-quality MCIS are trustworthy. To win the BT from consumers, each retailer should fully integrate its channels in all stages of shopping.
Before the purchase, the information of promotion, product, and price should be integrated, making it easy for consumers to sort and recognize information across different channels of the retailer, and reduce the perception of shopping risk, forming an initial trust.

During the purchase, the information acquisition and transaction information should be integrated, allowing consumers to switch freely between channels, and enjoy a convenient shopping environment. The integration helps to provide personalized services that deepen the trust.

After the purchase, the order fulfilment and consumer service should be integrated to minimize the risks in order placement, pick-up, and after-sales, and save the cost of shopping. In this way, the consumers will from the BT, thanks to the excellent shopping experience.

To further enhance the BT, the retailer is advised to build a unified data platform for online and offline channels, and create digital portraits of consumers on cloud based on multichannel information. Once the platform is ready, the retailer needs to push personalized information to consumers, and frequently communicate with them. Moreover, the purchase process in each and all channels must be simplified, offering a transparent, stable, and attractive shopping experience. 


\subsection{The BT partially mediates the impact of the MCISQ on the RBE}

The mediator variable causes the independent variable to affect the dependent variable. Our results show that the BT mediates $52.6 \%$ of the relationship between the MCISQ and the RBE. The significant mediating role of the BT reflects that a consumer's perception of the MCISQ will be partially transformed into the BT for the retailer, and thus determines his/her differential response to the retailer. This finding enriches the application of trust as a mediator in the field of management [33], highlighting the key mediating role of the $\mathrm{BT}$ in retail management. Meanwhile, the BT is proved to be an important internal reason for the impact of the MCISQ on the RBE. In the multichannel retailing environment, the retailer should enhance its brand equity by deepening the BT through improving the MCISQ, because a high quality MCIS leads to a safe, reliable, and honest BT perception among consumers.

\section{ACKNOWLEDGMENTS}

This paper was supported by Humanities and Social Science Planning Foundation of Ministry of Education in China, "Research on multichannel retail integration services from the perspective of corporate brand equity" (Grant No: 17YJA630080), and Supported by Program for the Innovative Talents of Higher Education Institutions of Shanxi in China (PTIT).

\section{REFERENCES}

[1] Dong, X.Z., Chao, G.L. (2018). Research on synergistic effect of $\mathrm{O} 2 \mathrm{O}$ strategy in multi-channel retail enterprises: Empirical analysis based on consumer RFM panel data. Foreign Economics \& Management, 40(8): 71-86. https://doi.org/10.16538/j.cnki.fem.2018.08.006

[2] Schramm-Klein, H., Wagner, G., Steinmann, S., Morschett, D. (2011). Cross-channel integration - is it valued by customers. The International Review of Retail, Distribution and Consumer Research, 21(5): 501-511. https://doi.org/10.1080/09593969.2011.618886

[3] Wallace, D.W., Giese, J.L., Johnson, J.L. (2004). Customer retailer loyalty in the context of multiple channel strategies. Journal of Retailing, 80(4): 249-263. https://doi.org/10.1016/j.jretai.2004.10.002

[4] Swoboda, B., Haelsig, F., Schramm-Klein, H., Morschett, D. (2009). Moderating role of involvement in building a retail brand. International Journal of Retail \& Distribution Management, 37(11): 952-974. https://doi.org/10.1108/09590550910999370

[5] Pappu, R., Quester, P. (2006). Does customer satisfaction lead to improved brand equity? An empirical examination of two categories of retail brands. Journal of Product \& Brand Management, 15(1): 4-14. https://doi.org/10.1108/10610420610650837

[6] Hu, T.L., Chang, C.Y., Hsieh, W.C., Chen, K.H. (2010). An integrated relationship on brand strategy, brand equity, customer trust and brand performance-an empirical investigation of the health food industry. International Journal of Organizational Innovation, 2(3): 89-106.
[7] Jahanzeb, S., Fatima, T., Butt, M.M. (2013). How service quality influences brand equity. International Journal of Bank Marketing, 31(2): 126-141. https://doi.org/10.1108/02652321311298735

[8] Sousa, R., Voss, C.A. (2006). Service quality in multichannel services employing virtual channels. Journal of Service Research, 8(4): 356-371. https://doi.org/10.1177/1094670506286324

[9] Oh, L.B., Teo, H.H. (2010). Consumer value co-creation in a hybrid commerce service-delivery system. International Journal of Electronic Commerce, 14(3): 3562. https://doi.org/10.2753/JEC1086-4415140303

[10] Cao, L., Li, L. (2015). The impact of cross-channel integration on retailers' sales growth. Journal of Retailing, 91(2):

198-216. https://doi.org/10.1016/j.jretai.2014.12.005

[11] Ailawadi, K.L., Keller, K.L. (2004). Understanding retail branding: conceptual insights and research priorities. Journal of Retailing, 80(4): 331-342. https://doi.org/10.1016/j.jretai.2004.10.008

[12] Jara, M., Cliquet, G. (2012). Retail brand equity: Conceptualization and measurement. Journal of Retailing \& Consumer Services, 19(1): 140-149. https://doi.org/10.1016/j.jretconser.2011.11.003

[13] White, R.C., Joseph-Mathews, S., Voorhees, C.M. (2013). The effects of service on multichannel retailers' brand equity. Journal of Services Marketing, 27(4): 259270. https://doi.org/10.1108/08876041311330744

[14] Pappu, R., Quester, P. (2006). A consumer-based method for retailer equity measurement: Results of an empirical study. Journal of Retailing \& Consumer Services, 13(5): 317-329. https://doi.org/10.1016/j.jretconser.2005.10.002

[15] Dick, A.S., Basu, K. (1994). Customer loyalty: toward an integrated conceptual framework. Journal of the Academy of Marketing Science, 22(2): 99-113. https://doi.org/10.1177/0092070394222001

[16] Munuera-Aleman, J.L., Delgado-Ballester, E., YagueGuillen, M.J. (2003). Development and validation of a brand trust scale. International Journal of Market Research, $\quad 45(1)$ : 35-54. https://doi.org/10.1177/147078530304500103

[17] Krishnan, H.S. (1996). Characteristics of memory associations: a consumer-based brand equity perspective. International Journal of Research in Marketing, 13(4): 389-405. https://doi.org/10.1016/S0167-8116(96)000213

[18] Garbarino, E., Johnson, M.S. (1999). The different roles of satisfaction, trust, and commitment in customer relationships. Journal of Marketing, 63(2): 70-87. https://doi.org/10.1177/002224299906300205

[19] Chaudhuri, A., Holbrook, M.B. (2001). The chain of effects from brand trust and brand affect to brand performance: The role of brand loyalty. Journal of Marketing, 65(2): 81-93. https://doi.org/10.1509/jmkg.65.2.81.18255

[20] Morgan, R.M., Hunt, S.D. (1994). The commitment-trust theory of relationship marketing. Journal of Marketing, 58(3): 20-38. https://doi.org/10.1177/002224299405800302

[21] Erden, T., Swait, J. (1998). Brand equity as a signaling phenomenon. Journal of Consumer Psychology, 7(2): 131-157. https://doi.org/10.1207/s15327663jcp0702_02

[22] Lau, G.T., Lee, S.H. (1999). Consumers' trust in a brand 
and the link to brand loyalty. Journal of Market-Focused Management, 4(4): 341-370. https://doi.org/10.1023/A:1009886520142

[23] He, H.W., Li, H.Y. (2011). Csr and service brand: the mediating effect of brand identification and moderating effect of service quality. Journal of Business Ethics, 100(4): 673-688. https://doi.org/10.1007/s10551-0100703-y

[24] Yoo, B., Donthu, N., Lee, S. (2000). An examination of selected marketing mix elements and brand equity. Journal of the Academy of Marketing Science, 28(2): 195-211. https://doi.org/10.1177/0092070300282002

[25] Melis, K., Campo, K., Breugelmans, E., Lamey, L. (2015). The impact of the multi-channel retail mix on online store choice: Does online experience matter. Journal of Retailing, 91(2): 272-288. https://doi.org/10.1016/j.jretai.2014.12.004

[26] Ribbink, D., Van Riel, A., Liljander, V., Streukens, S. (2004). Comfort your online customer: Quality, trust, and loyalty on the internet. Journal of Service Theory \& Practice, $14(6)$ 446-456. https://doi.org/10.1108/09604520410569784

[27] Singh, J., Sirdeshmukh, D. (2000). Agency and trust mechanisms in consumer satisfaction and loyalty judgments. Journal of the Academy of Marketing Science, 28(1): 150-167. https://doi.org/10.1177/0092070300281014

[28] Herhausen, D., Binder, J., Schoegel, M., Herrmann, A. (2015). Integrating bricks with clicks: Retailer-level and channel-level outcomes of online-offline channel integration. Journal of Retailing, 91(2): 309-325. https://doi.org/10.1016/j.jretai.2014.12.009

[29] Liao, C.H., Yen, H.R., Li, E.Y. (2011). The effect of channel quality inconsistency on the association between e-service quality and customer relationships. Internet Research, 21(4): 458-478. https://doi.org/10.1108/10662241111158326

[30] Sirdeshmukh, D., Singh, J., Sabol, B. (2002). Consumer trust, value, and loyalty in relational exchanges. Journal of Marketing, 66(1): $15-37$. https://doi.org/10.1509/jmkg.66.1.15.18449

[31] Chiou, J.S., Shen, C.C. (2006). The effects of satisfaction, opportunism, and asset specificity on consumers' loyalty intention toward internet portal sites. Journal of Service Management, $17(1)$ : 7-22. https://doi.org/10.1108/09564230610651552

[32] Kramer, R.M. (1999). Trust and distrust in organizations: Emerging perspectives, enduring questions. Annual Review of Psychology, 50(1): 569-598. https://doi.org/10.1146/annurev.psych.50.1.569

[33] Cropanzano, R., Mitchell, M.S. (2005). Social exchange theory: An interdisciplinary review. Journal of Management, 31(6): 874-900. https://doi.org/10.1177/0149206305279602

[34] Gulati, R., Sytch, M. (2008). The dynamics of trust. Academy of Management Review, 33(1), 276-278. https://doi.org/10.5465/amr.2008.27753143

[35] Marakanon, L., Panjakajornsak, V. (2017). Perceived quality, perceived risk and customer trust affecting customer loyalty of environmentally friendly electronics products. Kasetsart Journal of Social Sciences, 38(1): 2430. https://doi.org/10.1016/j.kjss.2016.08.012 